\title{
IDENTIFIKASI JENIS DAN PENGELOLAAN LIMBAH BAHAN BERBAHAYA DAN BERACUN RUMAH TANGGA: STUDI KASUS KELURAHAN PASAR TAIS KECAMATAN SELUMA KABUPATEN SELUMA
}

\author{
Terry Irawansyah Putra ${ }^{1)}$, Nanik Setyowati ${ }^{2)}$, Enggar Apriyanto ${ }^{3)}$ \\ ${ }^{1)}$ Dinas Lingkungan Hidup Kabupaten Seluma \\ ${ }^{2)}$ Jurusan Agroekoteknologi Fakultas Pertanian Universitas Bengkulu \\ 3) Jurusan Kehutanan FakultasPertanian Universitas Bengkulu
}

\begin{abstract}
ABSTRAK
Limbah Bahan Berbahaya dan Beracun (Limbah B3) adalah sisa suatu usaha dan/atau kegiatan yang mengandung B3. Jenis limbah B3 rumah tangga walaupun jumlah atau konsentrasi yang kecil tetap mengandung bahan berbahaya beracun. Tujuan penelitian ini adalah mengidentifikasi jenis dan menghitung volume/berat limbah B3 rumah tangga, mengetahui pemahaman dan pengelolaan limbah B3 yang dimiliki masyarakat, mendeskripsikan hubungan antara pendapatan dan pendidikan dengan pengetahuan dan pengelolaan limbah B3 rumah tangga serta menentukan rekomendasi tentang pengelolaannya. Metode analisis data pada penelitian ini menggunakan metode analisis deskriptif dengan menghitung volume dan jenis limbah B3 yang dihasilkan setiap rumah, pendataan sarana dan prasarana yang dimiliki oleh rumah tersebut dalam rangka pengelolaan limbah B3 dan melakukan survey dengan menggunakan questionnaire/deep. Hasil penelitian terhadap 69 responden selama 8 minggu, rata-rata rumah tangga setiap minggu menghasilkan limbah B3 cair 0,8 liter dan 0,4 kilogram limbah B3 padat. Limbah B3 cair berupa sisa produk pembersih, minyak goreng kotor, oli bekas, sedangkan limbah padat berupa kaleng kemasan insektisida, baterai, dan bohlam. Masyarakat telah memiliki tempat sampah di rumah, namun hanya sedikit yang memiliki tempat sampah terpisah, sebagian besar tidak mengetahui arti dan jenis limbah B3, masyarakat masih membuang semua jenis sampah secara tercampur. Tidak terdapat hubungan pendapatan dengan pengelolaan limbah B3 rumah tangga, namun terdapat hubungan pendapatan dengan timbulan limbah B3 rumah tangga di kelurahan Pasar Tais. Tidak terdapat hubungan antara latar belakang pendidikan dengan timbulan limbah B3 rumah tangga, namun terdapat hubungan tingkat pendidikan dengan pengetahuan dan pengelolaan limbah B3 rumah tangga di kelurahan Pasar Tais. Pemerintah harus menetapkan jenis-jenis limbah B3 yang bersumber dari limbah rumah tangga, memastikan pemberian label/tanda pada produk kebutuhan rumah tangga yang berpotensi menjadi limbah B3, dan mengedukasi masyarakat tentang potensi limbah B3 di sekitar mereka, serta pemerintah harus menyediakan sarana, prasarana serta pengelola limbah B3.
\end{abstract}

Kata Kunci : limbah, b3, rumah tangga, pengelolaan.

\section{PENDAHULUAN}

Limbah Bahan Berbahaya dan Beracun (Limbah B3) adalah sisa suatu usahadan/atau kegiatan yang mengandung B3 (Peraturan Pemerintah Nomor : 101
Tahun 2014).Jenis limbah B3 walaupun dalam jumlah atau konsentrasi yang sangat kecil akan tetapi tetap mengandung bahan berbahaya beracun/B3. Jenis limbah ini antara lain adalah batu baterai bekas, neon dan bohlam bekas, kemasan cat, kosmetik 
atau pelumas kendaraan yang umumnya mengandung bahan-bahan yang menyebabkan iritasi atau gangguan kesehatan lainnya contohnya seperti logam merkuri yang terkandung di dalam batu baterai pada umumnya (Astuti, 2010 ).

Produk limbah B3 dalam sampah permukiman dan komersial yang paling banyak dihasilkan adalah limbah B3 dari produk pembersih sedangkan distribusi sampah B3 dalam skala besar paling banyak dihasilkan adalah limbah B3 dari produk cat berbasis minyak (oil-based paint). Limbah B3 dalam rumah tangga di dalam sampah kota relatif sangat kecil. Limbah B3 rumah tangga tidak sampai 2 $\%$ dari sampah domestik. Limbah B3 yang berada di Tempat Pembuangan Sementara (TPS) sampah ataupun Tempat Pembuangan Akhir (TPA) sampah merupakan ancaman bagi lingkungan. Menurut US-AEP (United States Agency for Environment Protection), sebuah baterai bermerkuri di dalam enam ton sampah, sudah melebihi ambang batas merkuri yang diijinkan dalam limbah padat, dan satu galon oli bekas sudah cukup untuk mencemari sejuta galon air dan membentuk lapisan minyak seluas 3.7 hektar (Setiono, 2005).

Laju produktif sampah terus meningkat, tidak saja sejajar dengan laju pertumbuhan penduduk tetapi juga sejalan dengan meningkatnya pola konsumsi masyarakat. Disisi lain, kapasitas penanganan sampah yang dilakukan masyaraat maupun pemerintah daerah belum optimal. Sampah yang tidak dikelola dengan baik akan berpengaruh terhadap lingkungan dan kesehatan masyarakat sekitarnya. Tingkat pendidikan, tingkat pendapatan keluarga, perilaku terhadap kebersihan lingkungan, pengetahuan tentang peraturan persampahan dan kesediaan membayar retribusi sampah berkolerasi positif dengan cara pengelolaan sampah rumah tangga (Suyoto dan Bagong, 2008).

Selain masalah tersebut, bahaya lain yang ditimbulkan adalah masuknya bahan- bahan yang berkategori limbah B3 tersebut ke dalam aliran air bawah tanah atau kontak langsung dengan manusia dan mahluk hidup lainnya. Tingkat resiko bahaya terbesar sudah barang tentu diterima oleh para pelaku daur ulang dan petugas sampah umumnya yang biasa bekerja tanpa peralatan pelindung (Setiono, 2005).

Limbah B3 mempengaruhi kesehatan dengan mencelakakan manusia secara langsung (akibat ledakan, kebakaran, reaktif, korosif) maupun tidak langsung (toksik akut dan krosis). Limbah B3 masuk ke lingkungan melalui media air, tanah, udara, dan biota yang mempengaruhi secara kontinyu dan tidak kontinyu, bertahap dan seketika, teratur dan tidak teratur. Limbah B3 meracuni mahluk hidup melalui rantai makanan sehingga menyebabkan organisme (tumbuhan, hewan, dan manusia) terpapar oleh zat-zat beracun. Pegaruh limbah B3 terhadap mahluk hidup, Khususnya manusia adalah :

1. Efek akut, dapat menimbulkan kerusakan syaraf, kerusakan sitem pencernaan, kerusakan sitem kardio vasculer, kerusakan sitem pernafasan, kerusakan pada kulit dan kematian.

2. Efek krosis, menimbulkan efek karsinogenik (pendorong terjadinya kanker), efek mutagenik (pendorong mutasi sel tubuh), efek teratogenik (pendorong terjadinya cacat bawaan) dan kerusakan sitem reproduksi.

Bagian organ tubuh yang terkena pengaruh adalah :

- ginjal dan jantung : umumnya disebabkan zat toksik kadmium

- tulang : umumnya disebabkan zat toksik benzene

- otak dan sistem syaraf : umumnya disebabkan zat toksik methyl mercury dan timbal

- liver : umumnya disebabkan zat toksik karbon tetrachlorida

- Paru-paru : umumnya disebabkan zat toksik paraquat 
- Mata : umumnya disebabkan zat toksik khloroquin dan juga dikenal efek yang mempengaruhi pertumbuhan dan reproduksi. (Pusat Pengelolaan Ekoregion Sumatra. 2010).

Kabupaten Seluma secara administrasi termasuk ke dalam wilayah Provinsi Bengkulu yang dibentuk berdasarkan undang-undang Nomor 3 tahun 2003, tentang Pembentukan Kabupaten Muko-muko, Kabupaten Seluma dan Kabupaten Kaur. Secara Geografis Kabupaten Seluma terletak di Pantai Barat Sumatera bagian selatan yang berada pada koordinat lintang dan bujur, yaitu $03^{\circ} 49^{\prime} 55,66^{\prime \prime}$ LS - 0421'40,22” LS dan $101^{\circ} 17^{\prime} 27,57^{\prime \prime}$ BT - 102 $59^{\prime} 40,54^{\prime \prime}$ BT (Badan Pusat Statistik Kabupaten Seluma, 2018).

Pengelolaan sampah di Kabupaten Seluma dilakukan oleh Dinas Lingkungan Hidup Kabupaten Seluma, melalui Bidang Kebersihan pada dinas tersebut. Pengelolaan sampah masih dilakukan dengan mengumpulkan sampah langsung dari rumah - rumah warga, tanpa melalui pemisahan terlebih dahulu antara limbah domestik dan limbah yang mengandung B3, meskipun ada sebagian warga yang telah memilah limbah B3 di rumah, namun mereka tidak tau akan dibuang kemana limbah tersebut, pada akhirnya mereka menyerahkan limbah B3 tersebut kepada petugas kebersihan dan dikumpulkan menjadi satu dengan sampah domistik.

Berdasarkan uraian di atas, maka perlu dilakukan penelitian tentang identifikasi jenis dan pengelolaan limbah B3 yang bersumber dari rumah tangga di Ibu Kota Kabupaten Seluma. Penelitian yang dilakukan akan mencakup identifikasi jenis dan jumlah limbah B3, jumlah limbah B3 yang dihasilkan serta pengelolaan limbah B3 rumah tangga yang dilakukan saat ini berdasarkan sudut pandang masyarakat sebagai sumber penghasil limbah tersebut.

Penelitian ini bertujuan untuk mengidentifikasi jenis dan menghitung limbah B3 yang dihasilkan oleh rumah tangga, mengetahui pemahaman dan pengelolaan limbah B3 yang dimiliki masyarakat, mendeskripsikan hubungan antara pendapatan dan pendidikan dengan pengetahuan dan pengelolaan limbah B3 rumah tangga serta menentukan rekomendasi tentang pengelolaan limbah B3 rumah tangga.

\section{METODE PENELITIAN}

\section{Lokasi dan Waktu Penelitian}

Penelitian ini dilakukan di Kelurahan Pasar Tais, Kabupaten Seluma, Provinsi Bengkulu karena Penelitian ini dilaksanakan bulan Agustus sampai dengan Oktober 2018.

\section{Deskripsi Kelurahan Pasar Tais}

Kelurahan Pasar Tais memiliki luas $2.165 \mathrm{Km}^{2}$, yang terdiri dari $583 \mathrm{KK}, 3 \mathrm{RW}$ dan 9 RT (BPS,2015). Data dari Dinas Kependudukan dan Pencatatan Sipil Kabupaten Seluma adalah 690 KK

\section{Alat dan Bahan}

Peralatan yang digunakan pada penelitian ini adalah: Timbangan, gelas ukur, kamera, kantong plastik, ATK, dan bahan atau objek penelitian adalah limbah B3 yang dihasilkan oleh rumah tangga yang ada di Kelurahan Pasar Tais, Kecamatan Seluma Kabupaten Seluma, serta sarana prasarana pengelolaan limbah B3.

\section{Metode dan Analisis Data}

Metode analisis data yang digunakan pada penelitian ini menggunakan metode analisis deskriptif. Penelitian ini dilakukan dengan menghitung volume dan jenis limbah B3 yang dihasilkan setiap rumah, serta pendataan sarana dan prasarana yang dimiliki oleh rumah tersebut dalam rangka pengelolaan limbah B3, dengan melakukan survey dengan menggunakan questionnaire/deep interveiw untuk mengetahui keinginan masyarakat dalam mengelola limbah B3. 


\section{Jumlah dan Karakteristik Responden}

Jumlah kepala keluarga di

kelurahan Pasar Tais sebesar $690 \mathrm{KK}$.

Penelitian ini mengambil sampel sebanyak

$69 \mathrm{KK}$ atau $10 \%$ dari jumlah populasi (Arikunto, 2010). Sampel dari jumlah KK di Pasar Tais yang diambil kemudian dikelompokkan dalam 5 latar belakang pekerjaan yang terdiri dari wiraswasta (38 $\mathrm{KK})$, PNS (12 KK), pedagang (2 KK), petani (8 KK), dan profesi lainnya (9 KK). Profesi lainnya terdiri dari pensiunan, TNI, PHL, Polisi, pekerja serabutan, masih sekolah dan tinggal sendirian, pembantu rumah tangga dan penyapu jalan. Penentuan sampel dilakukan secara acak (random sampling).

\section{Prosedur Penelitian}

Prosedur penelitian yangdilakukan meliputi pengumpulan data primer dan data sekunder yang meliputi pendataan lokasi dan identitas pemilik rumah, pendataan jenis, volume dan karakteristik limbah B3 yang dihasilkan serta mendata sarana dan prasarana pengelolaan limbah B3 yang ada.

Tahapan penelitian yang dikerjakan sebagai berikut :

1. Mendata lokasi, identitas pemilik rumah meliputi nama pemilik, alamat, pekerjaan dan penghasilan.

2. Melakukan observasi dan wawancara dengan pemilik rumah seputar pengetahuan tentang limbah B3 dan bahayanya, sarana dan prasarana pengelolaan limbah B3 (kemasan dan tempat penyimpanan limbah B3), cara pengelolaan limbah B3 yang dihasilkan (apakah dijual ke penampung atau dibuang) dan mengisi lembar kuisioner yang telah disiapkan atau dengan melakukan wawancara.
3. Pengumpulan data limbah B3 rumah tangga dilakukan melalui prosedur sebagai berikut. Limbah B3 rumah tangga dikumpulkan oleh responden ke dalam penampungan plastik. Limbah yang telah terkumpul tersebut diambil setiap minggu kemudian dipisahkan antara limbah cair dan padat dan diukur volume maupun beratnya. Limbah padat ditimbang dengan mengguaakan timbangan, dan untuk limbah cair ukur dengan menggunakan gelas ukur, kegiatan tersebut dilakukan selama 8 minggu.

4. Setelah data-data didapat, dibuat tabulasi berdasarkan jenis limbah, volume limbah B3 yang dihasilkanmingguan dan bulanan serta pengelolaan limbah B3 yang ada.

\section{HASILDAN PEMBAHASAN}

Terdapat dua jenis limbah B3 yaitu limbah cair dan limbah padat dengan volume dan beratnya temuan di lapangan selama 1 minggu, 8 minggu dan asumsi selama 1 tahun (Tabel 2). Limbah B3 cair lebih banyak dibandingkan jenis limbah padat. Rata-rata setiap minggu, setiap rumah tangga menghasilkan limbah B3 cair 0,8 liter dan 0,4 kilogram limbah B3 padat. Limbah B3 cair sebagian besar adalah sisa produk pembersih, minyak goreng kotor dan oli bekas, limbah B3 padat berupa botol-botol kemasan insektisida, pestisida, lampu, dan baterai. Limbah cair yang dimaksud belum termasuk limbah B3 yang dihasilkan dari kegiatan cuci pakaian/laundry dan kegiatan cuci di dapur. 
Tabel 1.Timbulan Limbah B3 Rumah Tangga

\begin{tabular}{|c|c|c|c|c|c|c|c|}
\hline \multirow[t]{2}{*}{ No } & \multirow{2}{*}{$\begin{array}{c}\text { Kriteria } \\
\text { Responden }\end{array}$} & \multicolumn{2}{|c|}{$\begin{array}{l}\text { Volume Limbah } \\
\text { B3 / minggu }\end{array}$} & \multicolumn{2}{|c|}{$\begin{array}{l}\text { Volume Limbah } 8 \\
\text { mingggu }\end{array}$} & \multicolumn{2}{|c|}{$\begin{array}{c}\text { Asumsi Volume } \\
\text { Limbah } \\
1 \text { Tahun }\end{array}$} \\
\hline & & cair (1) & $\begin{array}{c}\text { padat } \\
(\mathrm{kg})\end{array}$ & cair (1) & $\begin{array}{c}\text { padat } \\
(\mathrm{kg})\end{array}$ & cair (l) & $\begin{array}{c}\text { padat } \\
(\mathrm{kg})\end{array}$ \\
\hline 1 & Wiraswasta & 28,1 & 12,8 & 224,5 & 102,5 & 1346,8 & 615,2 \\
\hline 2 & PNS & 15,5 & 9,0 & 123,7 & 71,8 & 742,4 & 430,8 \\
\hline 3 & Pedagang & 2,4 & 1,5 & 19 & 11,6 & 113,9 & 69,5 \\
\hline 4 & Petani & 3,6 & 1,7 & 28,5 & 13,4 & 171,3 & 80,2 \\
\hline \multirow[t]{2}{*}{5} & Profesi Lainnya & 8,2 & 5,4 & 65,8 & 43,1 & 395 & 258,7 \\
\hline & Total & 57,7 & 30,3 & 461,5 & 242,4 & 2769,3 & 1454,4 \\
\hline
\end{tabular}

Tabel 2.Rata - rata pendapatan dan latar belakang pendidikan serta timbulan limbah B3

\begin{tabular}{llrrrc}
\hline No & Kriteria Responden & \multicolumn{1}{c}{ Pendapatan $(\mathrm{Rp})$} & Pendidikan & Cair $(\mathrm{l})$ & $\begin{array}{c}\text { Padat } \\
(\mathrm{g})\end{array}$ \\
\hline 1. & Wiraswasta & $\geq 3.000 .000,-$ & SMA & 0,7 & 0,3 \\
2. & PNS & $2.000 .000,--3000.000,-$ & S1 & 1,3 & 0,7 \\
3. & Pedagang & $\geq 3.000 .000,-$ & SMA & 1,2 & 0,7 \\
4. & Petani & $1.000 .000,--2.000 .000,-$ & SD & 0,4 & 0,2 \\
5. & Profesi Lainnya & $2.000 .000,--3.000 .000,-$ & SMA & 0,9 & 0,6 \\
\hline
\end{tabular}
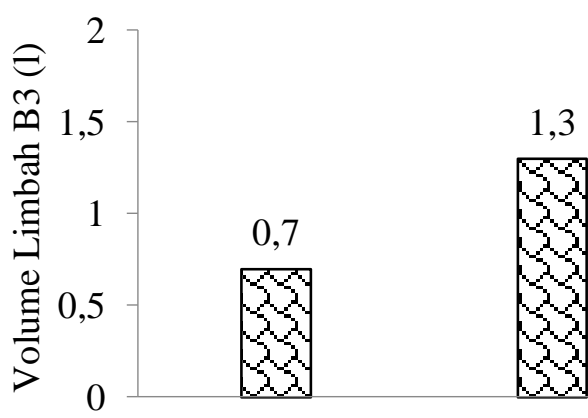
1,2

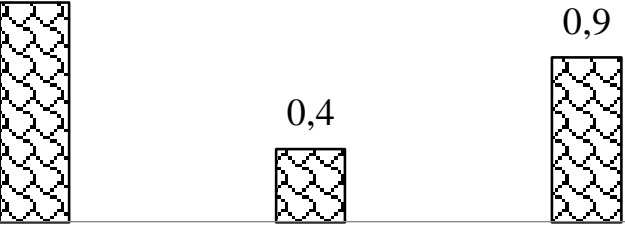

Wiraswasta

PNS

Pedagang

Petani

Profesi Lainnya

Gambar 1. Jumlah limbah B3 cair rumah tangga dalam 1 minggu

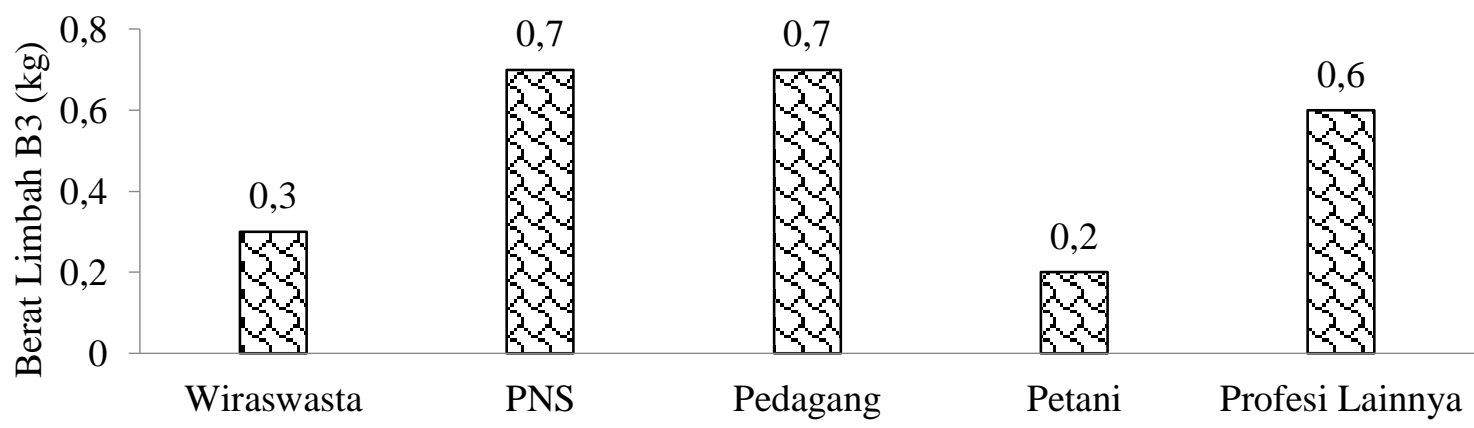

Gambar 2. Jumlah limbah B3 padat rumah tangga dalam 1 minggu 
Hasil penghitungan limbah B3 rata rata yang dihasilkan oleh responden menunjukkan bahwa responden dari latar belakang PNS yang rata - rata pendidikannya adalah $\mathrm{S} 1$ dengan penghasilan antara Rp. 2.000.000,- - Rp. 3.000.000,- menghasilkan limbah B3 lebih banyak dibandingkan dengan responden lainnya.

Hasil penelitian yang dilakukan juga menunjukkan bahwa latar belakang pendapatan dan pendidikan PNS tidak berpengaruh terhadap volume timbulan limbah B3. Meskipun memiliki penghasilan antara Rp. 2.000.000,- - Rp. 3.000.000,- dan pendidikan rata-rata $S 1$, namun volume limbah yang dihasilkan lebih tinggi dibandingkan dengan limbah yang dihasilkan oleh pedagang dan wiraswasta yang memiliki penghasilan diatas Rp. 3.000.000,- dengan tingkat pendidikan yang rata-rata SMA.

Hal ini lebih disebabkan karena penggunaan barang-barang yang mengandung limbah B3 pada responden PNS lebih besar dibandingkan responden lainnya. Limbah B3 tersebut antara lain produk aerosol, botol-botol kemasan insektisida, lampu, baterai, sisa produk pembersih dan bekas kemasan tinta. Slamet (2002) menyatakan salah satu faktor yang menyebabkan permasalahan sampah di Indonesia semakin rumit adalah meningkatnya taraf hidup masyarakat.

Limbah B3 yang dihasilkan di Kelurahan Pasar Tais sejauh ini masih dibuang bersamaan dengan limbah domestik ke TPS untuk selanjutnya dibawa ke TPA oleh petugas kebersihan. Sampai di TPA, kondisi antara limbah domestik dan limbah B3 masih tercampur. Kondisi ini menunjukkan belum adanya pengelolaan limbah B3 yang baik benar. Masih sedikitnya pengelolaan limbah B3 rumah tangga di kelurahan Pasar Tais ini tentu akan berpotensi menimbulkan akumulasi dari bahan berbahaya dan beracun yang ada di sekitar tempat limbah B3 tersebut dibuang. Akumulasi tersebut pada suatu saat akan dapat menyebabkan masuknya bahan-bahan yang berkategori B3 tersebut ke dalam lingkungan atau kontak langsung dengan manusia dan mahluk hidup lainnya apabila tidak dikelola dengan benar sesuai dengan perundangan dan peraturan yang berlaku.

Apabila tidak dikelola dengan baik maka limbah B3 dapat berdampak negatif terhadap lingkungan maupun kesehatan. Terhadap lingkungan, limbah B3 dapat masuk melalui media air, tanah, udara, dan biota. Limbah B3 dapat meracuni mahluk hidup melalui rantai makanan sehingga menyebabkan organisme (tumbuhan, hewan, dan manusia) terpapar oleh zat-zat beracun (Pusat Pengelolaan Ekoregion Sumatra, 2010). Limbah B3 juga berpengaruh terhadap kesehatan. Jenis penyakit yang ditimbulkan, pada umumnya merupakan penyakit non infeksi antara lain : keracunan, kerusakan orga, kanker, hypertensi, asma bronchioli, pengaruh pada janin yang dapat mengakibatkan lahir cacat (cacat bawaan), kemunduran mental, gagguan pertumbuhan baik fisik maupun psikis, gangguan kecerdasan dan sebagainya (Badan Pengendalian Dampak Lingkungan, 1998). 




Gambar 3. Persentase respon keseluruhan pemahaman responden terkait limbah B3

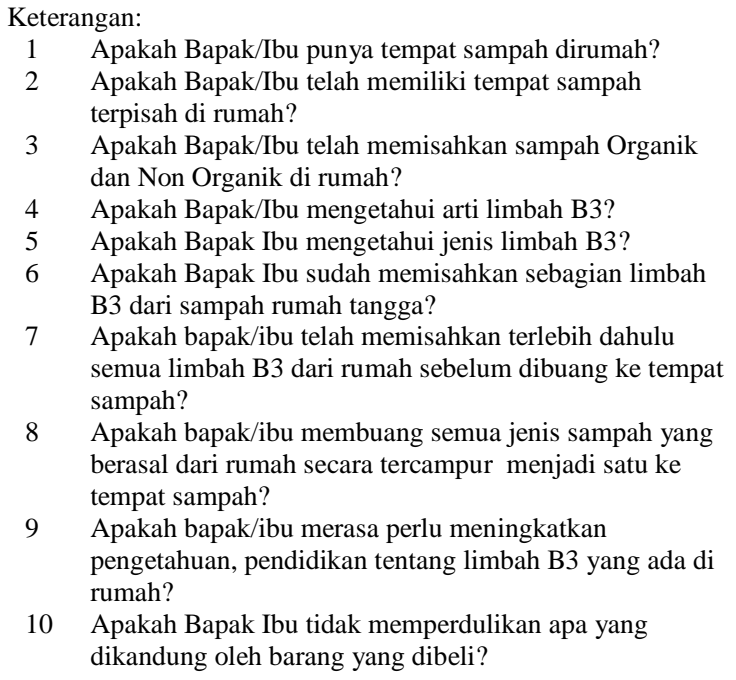

Hasil penelitian menunjukkan ratarata, $98 \%$ responden telah memiliki tempat sampah namun hanya $23 \%$ yang telah memisahkan sampah organik dan anorganik. Pengetahuan responden terhadap limbah B3 dan jenisnya masingmasing sebesar $21 \%$ dan $18 \%$. Meski demikian telah ada responden yang memisahkan limbah B3 dari sampah lainnya meskipun hanya sebesar $2,8 \%$. Sebagian besar responden (98\%) berkeinginan untuk meningkatkan pengetahuan mereka tentang limbah B3 rumah tangga.

Secara umum, seluruh responden telah memiliki tempat sampah namun mereka masih mencampur limbah B3 dengan sampah biasa atau belum memisahkan limbah B3. Mereka tidak mengetahui arti limbah B3 maupun jenisjenis limbah B3, namun berkeinginan untuk meningkatkan pengetahuannya tentang limbah B3. Diantara responden yaang diteliti, respon PNS terhadap pengetahuan dan pengelolaan limbah B3 lebih tinggi dibandingkan responden dengan latar belakang pekerjaan yang berbeda. Sebagian PNS telah memiliki tempat sampah terpisah, telah memisahkan sampah organik dengan anorganik, telah mengetahui arti dan jenis limbah B3 serta sudah memisahkan limbah B3.

Masih sedikitnya responden yang memisahkan limbah B3 diduga dikarenakan mereka malas untuk memisahkan limbah B3. Hal ini berhubungan dengan pengetahuan mereka tentang limbah B3 masih rendah. Disamaping itu Peraturan Pemerintah yang mengatur tentang pengolaan limbah B3 belum ada. Untuk itu perlu edukasi dan sosialisasi tentang pengelolaan limbah B3 kepada masyarakat dan perlu dibuat peraturan pemerintah tentang pengelolaan limbah B3 rumah tangga. Berdasarkan hasil penelitian yang dilakukan Gusti et, al. (2015) ada hubungan antara pengetahuan dengan sikap terhadap pengelolaan sampah berkelanjutan, ada hubungan pengetahuan tentang 
pengelolaan sampah berkelanjutaan dengan intensi perilaku pengelolaan sampah berkelanjutan. Salah satu komponen penting agar pembangunan berkelanjutan dan berwawasan lingkungan hidup dapat berjalan adalah dengan diberlakukannya peraturan perundangan lingkungan hidup sebagai dasar dalam menjaga kualitas lingkungan. Diberlakukannya peraturan maka hak, kewajiban dan kewenangan dalam pengeolaan limbah oleh setiap orang, badan usaha, maupun orgaisasi kemasyarakatan dijaga dan dilindungi oleh hukum (Setiyono, 2001). Menurut Pertiwi et, al. (2017) perlu dibentuk program khusus untuk pengurangan limbah B3, kebijakan dan standar operasional prosedur (SOP) sebagai upaya pengurangan limbah B3.

Hasil penelitian yang dilakukan Rahim et al (2016), menunjukkan pengetahuan warga tentang sampah B3 mencapai $46 \%$ sedangkan $54 \%$ tidak mengetahui sama sekali. Kecilnya pengetahuan responden yang diteliti tentang limbah B3 diduga karena kurangnya sosialisasi yang dilakukan oleh Pemerintah. Untuk itu Pemerintah perlu melakukan sosialisasi tentang limbah B3 kepada masyarakat.

Suhadi (2012) dalam pelitiannya menjelaskan bahwa sosialisasi tentang limbah B3 kepada masyarakat dan pihakpihak yang menjadi sumber limbah B3 merupakan upaya yang paling mungkin dilakukan sebagai langkah preventif. Selain itu perlu dilakukan penelitian lapangan untuk memetakan sumber limbah B3 secara lebih komprehensif.

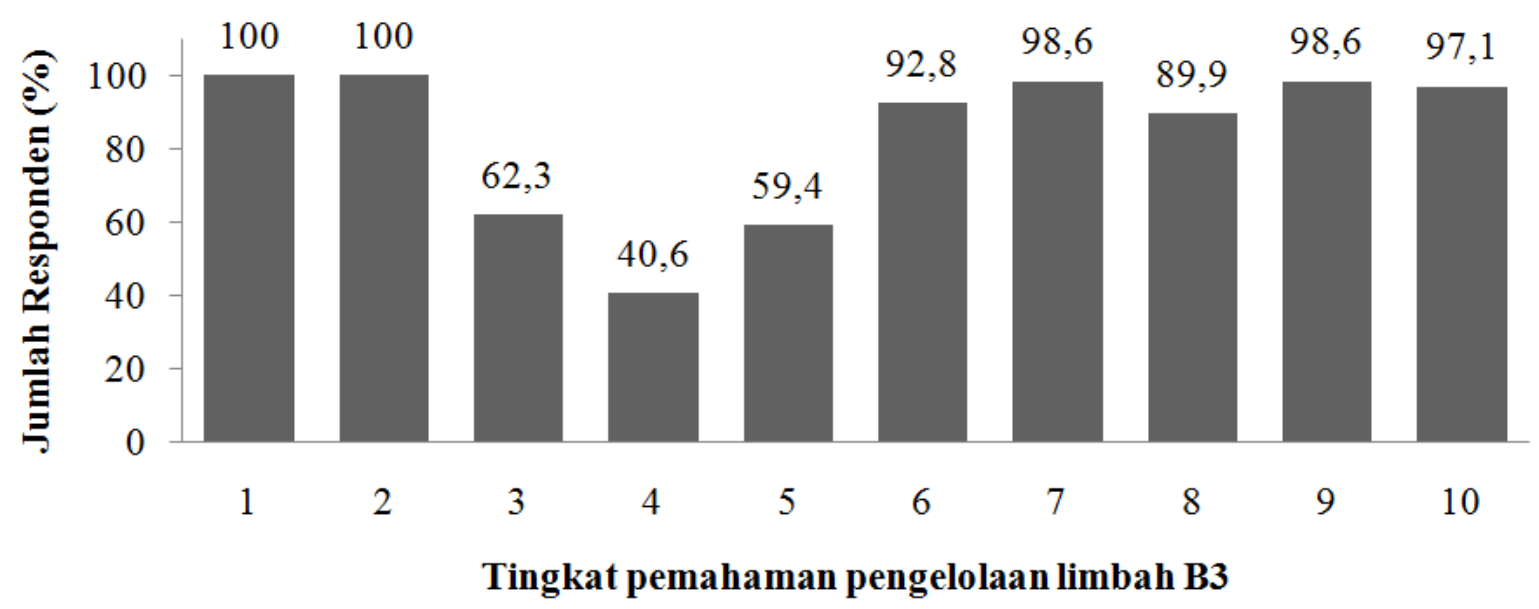

Gambar 4. Persentase keseluruhan pemahaman dan keinginan responden

Keterangan:

1 Apakah Bapak/Ibu ingin rumah bersih dari sampah dan limbah B3?

2 Apakah Bapak/Ibu ingin ada pengelola limbah B3 Di lingkungan anda?

3 Bersediakan Bapak/Ibu membayar retribusi limbah B3?

4 Apakah Bapak/Ibu bersedia menyediakan tempat limbah B3 terpilah secara swadaya?

5 Apakah Bapak/Ibu bersedia melakukan pemilahan limbah B3 sebelum dibuang ke tempat sampah?

6 Apakah Bapak Ibu bersedia mebayar retribusi jika pemerintah menyediakan pengelola/petugas limbah B3 untuk melayani lingkungan bapa/ibu?
7 Apakah bapak/ibu bersedia membayar retribusi jika pemerintah bersedia menyediakan tempat limbah B3 terpilah dan ada pengelola limbah B3 untuk melayani lingkungan anda?

8 Apakah bapak/ibu bersedia memilah limbah B3 sendiri jika tempat sampah terpilah disediakan oleh pemerintah?

9 Apakah bapak/ibu peduli akan adanya limbah B3 dari aktivitas rumah tangga?

10 Apakah Bapak/Ibu akan mematuhi kebijakan pemerintah daerah tentang pengelolaan limbah B3 walaupun tidak sesuai dengan pendapat yang anda berikan?

Seluruh responden berkeinginan lingkungan rumahnya bersih (100\%). Mereka juga berkeinginan ada 
pengelolalimbah B3 di lingkungan tempat tinggal mereka (100\%), bersedia membayar retribusi untuk pengelolaan sampah sebanyak 62,3\%. Hanya 40,5\% yang bersedia menyediakan tempat limbah B3 terpilah secara swadaya. Namun jika pemerintah menyediakan pengelola dan sarana prasarana pengelolaan limbah B3, sebesar 98,6\% responden sangat bersedia membayar retribusi dan namun yang bersedia memilah limbah B3 hanya 89,9\%. Hasil penelitian secara umum menunjukkan terdapat hambatan dalam pengelolaan limbah B3 rumah tangga yang meliputi ketidak pedulian masyarakat serta tidak tersedianya sarana dan prasarana yang memadai. Ketidakpedulian masyarakat dalam pengelolaan limbah B3 lebih dikarenakan kurang pengetahuan mereka. Untuk itu diperlukan edukasi kepada masyarakat serta sangsi bagi yang melanggar.

Hasil penelitian Hasibuan (2016) menunjukkan perlu adanya penegakan hukum terhadap pelaku pencemaran lingkungan hidup serta memberikan sanksi yang berat. Terhadap limbah rumah tangga diperlukan adanya aturan jelas dan tegas serta adanya sosialisasi yang terus menerus kepada masyarakat tentang pengelolaan limbah rumah tangga.Hambatan dalam pengelolaan limbah rumah tangga karena adanya ketidakpedulian dari lingkungan rumah tangga itu sendiri, kurangnya peran dari masyarakat itu sendiri, kurangnya ketersediaan tempat sampah dari pemerintah serta tidak adanya perencanaan dari perusahaan tentang kemasan yang dapat didaur ulang.

Penelitian Setiyono (2005) yang dilakukan di Jakarta juga menunjukkan, tingkat pengetahuan masyarakat tentang sampah B3 masih sangat minim sekali. Disamping itu juga tidak tersedia fasilitas khusus untuk mengelola limbah B3 yang dapat dimanfatkan oleh masyarakat.Tidak adanya petugas lapangan dan tidak tersedianya sarana pengelolaan limbah B3 di tingkat masyarakat umum juga menyebabkan limbah B3 yang dihasilkan oleh masyarakat tercampur dengan sampah domestik. Penyuluhan untuk memberikan pengetahuan tentang limbah B3 di tingkat masyarakat perlu dilakukan dan perlu segera dirintis penyediaan fasilitas di tingkat masyarakat umum untuk menampung limbah B3 dari sektor domestik.

\section{Hubungan antara Pendapatan dan Pendidikan Responden terhadap Pengelolaan Limbah B3.}

Tidak ada keterkaitan antara pendapatan keluarga dengan pengetahuan dan pengelolaan limbah B3. Mereka dengan pengasilan yang tinggi tidak serta merta mau mengelola limbah B3 dengan baik. Jika dilihat dari identitas responden, maka yang berpengahasilan diatas 3 juta memiliki pekerjaan sebagai wiraswasta dan pedagang, diduga ada keterkaitan antara pekerjaan dengan kemauan untuk mengelola limbah B3.

Hasil penelitan ini sedikit berbeda dengan hasil penelitian Pangestu (1995) yang menunjukkan tingkat pendapatan keluarga memberikan pengaruh yang besar terhadap kegiatan penanganan sampah. Orang yang memiliki pendapatan tinggi cenderung melakukan penanganan lebih baik, misalnya, mereka akan menyediakan tempat sampah di dalam maupun di luar rumah serta membayar orang lain untuk menangani sampah yang mereka hasilkan. Tingkat pendapatan keluarga berpengaruh positif dengan sikap keluarga terhadap pengelolaan sampah rumah tangga. Semakin tinggi pendapatan keluarga, akan semakin tinggi pula sikapnya untuk mengelola sampah rumah tangga (Putra et. al 2013).

Hasil pengamatan pada tingkat pendidikan, terdapat keterkaitan antara tingkat pendidikan dengan pengetahuan dan pengelolaan limbah B3. Responden dengan tingkat pendidikan S1 memiliki pengetahuan tentang limbah B3 lebih baik dibandingkan dengan jenjang pendidikan 
lainnya. Jika dikaitkan dengan pengelolaanya, maka yang memiliki jenjang S1 lebih mendukung pengelolaan limbah B3. Mereka bersedia membayar retribusi serta mau menyiapkan tempat limbah B3. Dengan pendidikan yang tinggi, (S1) mereka diduga memiliki pengetahuan tentang limbah B3 dan dampak negatif yang ditimbulkan yang didapatkan melalui informasi tertulis seperti buku, koran maupun media elektronik seperti TV, media online maupun radio. Hasil penelitian ini sejalan dengan yang dilakukan oleh Putri (2017) yang menjelaskan bahwa terdapat hubungan yang positif antara tingkat pendidikan dan tingkat pengetahuan dengan perilaku hidup sehat. Di sisi lain, hasil penelitian yang dilakukan di Kelurahan Bener, Kecamatan Tegalrejo, Yogyakarta Sari dan Mulasari (2017) menunjukkan tidak terdapat hubugan antara tingkat pendidikan dengan perilaku pengelolaan sampah.

Semua responden, tanpa melihat melihat jenjang pendidikan, mereka menginginkan rumahnya bersih, menghendaki adanya pengelola limbah B3 di lingkungan mereka, bersedia membayar retribusi jika pemerintah menyediakan sarana dan pengelola limbah B3. Disamping itu mereka akan mematuhi kebijakan yang dikeluarkan pemerintah tentang pengelolaan limbah B3. Dengan demikian mereka tidak berkeberatan untuk mengeluarkan dana pengelolaan limbah B3 agar lingkungan mereka bersih.

Menurut Putra et.al. (2013) tingkat pendidikan berpengaruh positif dengan sikap keluarga terhadap pengelolaan sampah rumah tangga. Semakin tinggi tingkat pendidikan, maka semakin baik pula sikapnya terhadap pengelolaan sampah dan semakin tinggi pendapatan keluargasemakin tinggi juga sikapnya untuk mengelola sampah rumah tangga.Tingkat pendidikan dan tingkat pendapatan secara bersama-sama memberikan hasil positif mempengaruhi sikap keluarga terhadap pengelolaan sampah rumah tangga. Se- makin tinggi tingkat pendidikan dan pendapatan keluarga di Desa Condongcatur , semakin tinggi pula sumbangan positif yang diberikan dalam menentukan sikapnya untuk mengelola sampah rumah tangga. Dalam penelitian ini, tingkat pendidikan keluarga responden rata-rata SMA dan S1 dengan pendapatan rata-rata diatas 3 juta per bulan.

Faktor keadaan masyarakat dalam tingkat pendidikan sangat berpengaruh terhadap keikutsertaan seseorang dalam mengelola sampah. Tingkat pendidikan seseorang mempengaruhi tingkat partisipasinya dalam sebuah kegiatan. Semakin tinggi pendidikan seseorang maka semakin mudah memberi informasi dan pembinaan ( Pangestu, 1995)

Hasil penelitian Putra, et al. (2013) juga menunjukkan tingkat pendidikan keluarga berpengaruh positif dengan sikap keluarga terhadap pengelolaan sampah rumah tangga. Semakin tinggi tingkat pendidikan maka semakin baik pula sikapnya terhadap pengelolaan sampah

Jika dikaitkan pendapatan dan tingkat pendidikan responden di dalam latar belakang pekerjaan, responden yang berasal dari PNS telah mengerti tentang limbah B3 (58\%) dan sebanyak 50\% sudah memisahkan limbah B3-nya. Meski demikian mereka masih mau meningkatkan pengetahuan tentang limbah B3 dan bersedia membayar retribusi pengelolaan limbah B3 tanpa syarat (100\%). Hal ini karena mereka memiliki tingkat pendidikan yang tinggi (Sarjana/S1) dengan penghasilan diatas $\mathrm{Rp}$. 2.000.000,-.

Hasil penelitian yang dilakukan pada responden dengan latar belakang wiraswasta menujukkan hasil yang agak berbeda dengan PNS. Sebagian besar mereka $(>70 \%)$ tidak bersedia menyediakan tempat sampah terpisah maupun memilah limbah B3-nya, namun jika pemerintah menyediakan tempat limbah B3 terpisah mereka bersedia membayarnya. Hal ini berkaitan dengan tingkat pendidikan mereka sebagian besar 
SMA atau di bawahnya namun memiliki pendapatan yang tinggi, diatas $\mathrm{Rp}$. 3.000.000,- juta.

Pemahaman responden petani tentang limbah B3 berbeda dengan PNS maupun wiraswasta. Pengetahuan mereka tentang limbah B3 sangat rendah (100\%), mereka yang bersedia menyediakan tempat sampah limbah B3 terpilah secara swadaya hanya $12 \%$. Namun meski demikian mereka sangat ingin meningkatkan pengetahuannya tentang limbah B3. Sebagain besar dari mereka tidak bersedia membayar retribusi (82\%). Hal ini berkaitan dengan tingkat pendidikan mereka yang sebagian besar hanya SD dengan pendapatan yang lebih rendah dibandingkan PNS dan wiraswasta, hanya Rp. 1.000.000,- - Rp. 2.000.000,- tiap bulannya.

\section{KESIMPULAN}

Kesimpulan dari hasil penelitian ini adalah:

1. Ditemukan dua jenis limbah B3 yaitu limbah cair dan limbah padat. Limbah cair yang ditemukan adalah sisa produk pembersih, minyak goreng kotor, oli sedangkan limbah padat berupa kaleng kemasan insektisida, baterai, dan bohlam. Selama 8 minggu observasi, rata-rata rumah tangga setiap minggu menghasilkan limbah B3 cair 0,8 liter dan 0,4 kilogram limbah B3 padat.

2. Masyarakat telah memiliki tempat sampah di rumah, namun hanya sedikit yang memiliki tempat sampah terpisah, sebagian besar tidak mengetahui arti dan jenis limbah B3, masyarakat masih membuang semua jenis sampah secara tercampur ke dalam satu tempat sampah.

3. Tidak terdapat hubungan pendapatan dengan pengelolaan limbah B3 rumah tangga, namun terdapat hubungan pendapatan dengan timbulan limbah B3 rumah tangga di kelurahan Pasar
Tais. Tidak terdapat hubungan antara latar belakang pendidikan dengan timbulan limbah B3 rumah tangga, namun terdapat hubungan tingkat pendidikan dengan pengetahuan dan pengelolaan limbah B3 rumah tangga di kelurahan Pasar Tais.

4. Pemerintah harus menetapkan jenisjenis limbah B3 yang bersumber dari limbah rumah tangga, memastikan pemberian label/tanda pada produk kebutuhan rumah tangga yang berpotensi menjadi limbah B3, mengedukasi masyarakat tentang potensi limbah B3 yang ada di sekitar mereka, dan pemerintah juga harus menyediakan sarana, prasarana dan pengelola limbah B3 untuk skala kabupaten.

\section{DAFTAR PUSTAKA}

Arikunto, S. 2010. Prosedur Penelitian Suatu Pendekatan Praktik. Jakarta: Rineka Cipta

Astuti W. 2010. Peran Sampah B3 Rumah Tangga (Household Hazardous Waste) dalam Peningkatan Global Warming. Prosiding Seminar Nasional Sains dan Teknologi Fakultas Teknik Universitas Wahid Hasim Semarang 1(1) : I.31I.36.https://publikasiilmiah.unwahas. ac.id/index.php/PROSIDING_SNST FT/article/view/350/425

Badan Pusat Statistik Kabupaten Seluma. 2018. Kabupaten Seluma dalam Angka Seluma Regency in Figures2018.

Deputi Menteri Lingkungan Hidup Bidang Penaatan Lingkungan. 2009. Peraturan Menteri Negara Lingkungan Hidup Nomor 30 Tahun 2009 tentang Tata Laksana Perizinan dan Pengawasan Pengelolaan Limbah Bahan Berbahaya dan Beracun Serta Pengawasan Pemulihan Akibat Pencemaran 
Limbah Bahan Berbahaya dan Beracun oleh Pemerintah Daerah. Jakarta.

Gusti, A., B. Isyandi, S. Bahri dan D. Afandi. 2015. Hubungan pengetahuan, sikap, dan intensi perilaku pengelolaan sampah berkelanjutan pada siswa sekolah dasar di Kota Padang. Dinamika Lingkungan Indonesia, 2(2):100-107

Hasibuan, R.2016. Analisis dampak limbah/sampah rumah tangga terhadappencemaran lingkungan hidup.Jurnal Ilmiah Advokasi, 4 (1): 42-51

Kepala Badan Pengendalian Dampak Lingkungan.1998.Keputusan Kepala Badan Pengendalian Dampak Lingkungan Nomor Kep03/Bapedal/01/1998 tentang Program Kemitraan dalam Pengelolaaan Limbah Bahan Berbahaya dan Beracun. Jakarta.

Kementerian Sekretariat Negara Republik Indonesia. 2014. Peraturan Pemerintah Repulik Indonesia Nomor 101 Tahun 2014 tentang Pengelolaan Limbah Bahan Berbahaya dan Beracun, Jakarta.

Pangestu, M.H.T. 1995. Pertisipasi masyarakat dalam pelaksanaan kegiatan perhutanan sosial (Studi Kasus: KPH Cianjur, Jawa Barat). Tesis Pascasarjana. Institut Pertanian Bogor, Bogor.

Pertiwi, V., Joko, T. Dan Dangiran, H.L. 2017. Evaluasi pengelolaan limbah bahan berbahaya dan beracun (B3) di rumah sakit Roemani Muhammadiyah, Semarang. Jurnal Kesehatan Masyarakat (e-Journal) 5(3):420-430.

Pusat Pengelolaan Ekoregion Sumatra. 2010 . Suara Bumi, Limbah Bahan Berbahaya dan Beraun (B3) di Sekitar Kita, Pekan Baru.

Putra,H.P., Taufiq,A.R., dan Juliani, A., 2013. Studi hubungan antara tingkat pendidikan dan pendapatan keluargaterhadap sikap dalam pengelolaan sampah rumah tangga(studi kasus di Desa Condongcatur, Depok, Sleman, Yogyakarta).Jurnal Sains dan Teknologi Lingkungan, 5 (2): 91-101

Putri, R. 2017. Hubungan antara tingkat pendidikan dan tingkat pengetahuan dengan perilaku hidup sehat kualitas lingkungan rumah (Studi Masyarakat Kabupaten Pringsewu, Kelurahan Pringsewu Barat). Skripsi. Fakultas Ilmu Sosial dan Ilmu Politik Universitas Lampung, Bandar Lampung.

Rahim,I., R., Mustari A., S., Muhyiddin M., M., 2016. Studi pengelolaan sampah B3 rumah tangga diKelurahan Mangasa Kecamatan Tamalate Kota Makassar http://repository.unhas.ac.id/handle/1 23456789/18801 diakses 05 Juni 2018.

Sekretriat Negara Republik Indonesia.2009.Undang-Undang

Republik Indonesia Nomor 32 Tahun 2009 tentang Perlindungan dan Pengelolaan Lingkungan Hidup, Jakarta.

Setiono.2005. Potensi Limbah B3 di wilayah DKI Jakarta dan strategi pengelolaannya. Journal of Accounting and Investment, 1 (3): 304-317.

Setiyono. Dasar Hukum Pengelolaan Limbah B3. 2001. Jurnal Teknologi Lingkungan, 2(1):72-77

Sekretariat Pemerintah Kabupaten Seluma. 2015. Peraturan Bupati Seluma Nomor 09 Tahun 2015 tentang Pengelolaan Persampahan di Lingkungan Pemerintahan Kabupaten Seluma, Tais.

Slamet, J.S. 2002. Kesehatan Lingkungan. Gadjah Mada University Press, Yogyakarta.

Suhadi, 2012 Mengawal limbah bahan berbahaya danberacun di kawasan sekaran untuk masadepan yang lebih baik. Indonesian Journal of Conservation, 1 (1): 87-94 
P-ISSN: 2302- 6715

E-ISSN: 2654- 7732

Suyoto, B. 2008. Rumah Tangga Peduli Lingkungan. Prima Media, Jakarta. 